Original Research Paper

\title{
Penyuluhan Tentang Dampak Perkawinan Dini Bagi Remaja di SMA Negeri 2 Gerung Kabupaten Lombok Barat
}

\author{
Muhammad Mabrur Haslan ${ }^{1 *}$, Yuliatin', Ahmad Fauzan'1, I Nengah Agus Tripayana1 \\ ${ }^{\text {I} P r o g r a m ~ S t u d i ~ P e n d i d i k a n ~ P a n c a s i l a ~ d a n ~ K e w a r g a n e g a r a a n, ~ F a k u l t a s ~ K e g u r u a n ~ d a n ~ I l m u ~ P e n d i d i k a n, ~ U n i v e r s i t a s ~ M a t a r a m, ~}$ \\ Mataram, Indonesia
}

DOI: https://doi.org/10.29303/jpmpi.v4i2.815

Sitasi: Haslan, M. M., Yuliatin., Fauzan, A, \& Tripayana. I. N. A. (2021). Penyuluhan Tentang Dampak Perkawinan Dini Bagi Remaja di SMA Negeri 2 Gerung Kabupaten Lombok Barat. Jurnal Pengabdian Magister Pendidikan IPA, $4(2)$

\section{Article history}

Received: 23 Maret 2021

Revised: 20 Mei 2021

Accepted: 23 Juni 2021

*Corresponding Author: Muhammad Mabrur Haslan, Program Studi Pendidikan Pancasila dan

Kewarganegaraan, Fakultas Keguruan dan Ilmu Pendidikan, Universitas Mataram, Mataram, Indonesia;

Email:

mabrurm41@yahoo.co.id

\begin{abstract}
Kasus pernikahan dini di Indonesia semakin memperhatikan. Menurut United Nations Children'es Fund (UNICEF) pada tahun 2013, Indonesia menjadi negara dengan angka perkawinan tertinggi ketujuh dunia. Kemudian menurut Survei Sosial Ekonomi (Susenas) tahun 2015, sebanyak 1 dari 4 anak perempuan di bawah usia 18 tahun pernah menikah. Kemudian pada tahun 2017, sebanyak 2 dari 5 anak perempuan usia 0-17 tahun pernah menikah. Angka tersebut menunjukkan bahwa Indonesia masih perlu menaruh perhatian lebih pada kasus pernikahan usia dini. Kegiatan pengabdian pada masyarakat ini dilakukan dengan tujuan agar khalayak sasaran, yaitu siswa SMAN 2 Gerung Kabupaten Lombok Barat dapat:a. Memahami faktor-faktor penyebab terjadinya pernikahan dini di kalangan remaja, Memahami dampak fisik dan psikis pernikahan dini pada remaja., Memahami solusi untuk mencegah pernikahan dini di kalangan remaja. Metode pelaksanaan kegiatan adalah penyluhan dan FGD. Metode penyuluhan digunakan untuk memberikan informasi atau pengetahuan tentang faktor-faktor penyebab perkawinan dini dan dampak perkawinan dini bagi siswa di SMA Negeri 2 Gerung Kabupaten Lombok Barat. Sedangkan Focus Group Discussion digunakan dalam rangka mencari solusi atau upaya untuk mencegah perkawinan dini bagi siswa di SMA Negeri 2 Gerung Kabupaten Lombok Barat. Solusi dalam mencegah perkawinan dini, yaitu: pelatihan terkait kampanye perlindungan anak juga menyasar pada penyedia layanan di masyarakat, pelatihan di lingkungan sekolah, diarahkan langsung kepada anak-anak, pembelajaran kepada keluarga. Target luaran adalah terpolanya pengetahuan dan pemahaman tentang faktor-faktor penyebab terjadi pernikah dini di kalangan remaja, terpolanya pengetahuan dan pemahaman tentang dampak pernikahan dini di kalangan remaja, terpolanya solusi untuk mencegah terjadinya pernikahan dini di kalangan remaja.
\end{abstract}

Keywords: Pernikahan Dini; Faktor Penyebab; Solusi; Lombok Barat. 


\section{Pendahuluan}

Maraknya pernikahan dini akan berkonstribusi pada tingginya angka kematian wanita saat melahirkan. Hal itu berkaitan dengan kesiapan rahim seorang wanita di saat memiliki keturunan pertama kali. Pada usia 10-19 tahun, rahim yang dimiliki seorang wanita masih tergolong belum matang sehingga menikah dan hamil di usia itu beresiko tinggi, seperti terjadinya pendaharan, keguguran, kematian janin dalam rahim ibu, dan lain sebagainya, dalam istilah lain, fenomena ini dinamakan early childbearing (resiko kehamilan ibu muda) (Desiyanti , 2015: 12).

Kasus pernikahan dini di Indonesia semakin memprihatinkan. Menurut United Nations Children"s Fund (UNICEF) pada tahun 2013, Indonesia menjadi negara dengan angka perkawinan tertinggi ketujuh dunia. Kemudian menurut Survei Sosial Ekonomi (Susenas) tahun 2015, sebanyak 1 dari 4 anak perempuan di bawah usia 18 tahun pernah menikah. Kemudian pada tahun 2017, sebanyak 2 dari 5 anak perempuan usia 0-17 tahun pernah menikah. Angka tersebut menunjukkan bahwa Indonesia masih perlu menaruh perhatian lebih pada kasus pernikahan usia dini.

Tingginya pernikahan dini di Indonesia, sebenarnya cenderung terjadi di pedesaan. Hal ini dikarenakan masyarakat yang tinggal di pedesaan masih rendah pemgetahuannya tentang dampak melakukan pernikahan dini di usia muda (BPS, 2015:17). Terlebih, berdasarkan analisis survey Penduduk Antar Sensus (SUPAS) 2005, oleh Badan Koordinasi Keluarga Berencana Nasional (BKKBN) menyimpulkan bahwa angka pernikahan dini di pedesaan lebih besar dibandingkan dengan perkotaan yang didapatkan untuk kelompok yang menikah (umur 15-19 tahun) sebanyak 5,28\% terjadi di perkotaan, dan $11,88 \%$ terjadi di pedesaan. Pernikahan dini tersebut paling banyak dilakukan pada perempuanperempuan berstatus pendidikan rendah (BKKBN, 2012: 11).

Secara umum, pernikahan dini dipengaruhi oleh beberapa faktor. Faktor yang sering dikaitkan dengan kondisi ini adalah faktor ekonomi, tingkat pendidikan yang kurang, faktor adat, pengaruh media massa, dan kondisi-kondisi tertentu seperti kehamilan di luar nikah. Faktor ekonomi biasanya terjadi karena keluarga mengalami kesulitan ekonomi sehingga terpaksa menikahkan anaknya pada usia dini, dengan begitu diharapkan sang anak dapat mengurangi beban ekonomi keluarga dan memperoleh kehidupan yang lebih layak.

Tingkat pendidikan yang rendah menyebabkan orang tua cenderung pasrah dan tidak terlalu memikirkan dampak yang akan dialami sang anak. Hal tersebut mengakibatkan faktor pendidikan juga dapat menjadi penentu usia pernikahan. Faktor adat atau tradisi juga dapat berpengaruh karena adanya kebiasaan pada suatu kelompok, contohnya seperti keyakinan untuk tidak menolak pinangan dari pria walaupun sang wanita belum berusia 16 tahun karena hal tersebut dianggap menghina. Faktor ini diyakini menyumbang persentase angka kejadian pernikahan dini di Indonesia.

Faktor media massa yang akhir-akhir ini memang sedang marak terjadi, mudahnya akses internet memudahkan masyarakat untuk membuka situs-situs berbau pornografi yang sebenarnya dilarang oleh pemerintah. Mirisnya banyak sekali remaja yang tidak dibekali pengetahuan dan emosional yang cukup untuk mengakses situs tersebut sehingga mereka akan merasa penasaran dan melakukan hubungan seks diluar nikah.

Pernikahan usia dini dapat menimbulkan banyak dampak negatif bagi kesehatan pasangan. Berdasarkan Laporan Kajian Perkawinan Usia Anak di Indonesia, tingginya angka pernikahan usia dini dapat meningkatkan risiko kematian ibu dan bayi. Selain itu, pernikahan usia dini juga dapat menimbulkan dampak bagi kesehatan anak-anak mereka di kemudian hari. Jika dilihat dari segi kesehatan fisik perempuan, organ reproduksi pada perempuan di bawah usia 20 tahun belum matang dengan sempurna. Perempuan yang melakukan aktivitas seksual di bawah usia 20 tahun dapat berisiko menimbulkan berbagai penyakit, seperti kanker serviks dan kanker payudara.

Selain itu, kehamilan di bawah usia 20 tahun dapat menimbulkan risiko perdarahan, anemia, pre-eklampsia dan eklampsia, infeksi saat hamil, dan keguguran. Perempuan yang hamil dan melahirkan pada usia 10-14 tahun memiliki risiko $5 \mathrm{x}$ lebih besar dibandingkan dengan perempuan berusia 20-24 tahun. Kehamilan pada usia dini penuh risiko, selain itu janin dari ibu tersebut juga berisiko mengalami masalah kesehatan, seperti kelahiran prematur. Bayi yang lahir prematur dapat berisiko mengalami gangguan pernapasan, pencernaan, penglihatan, hingga penurunan 
kemampuan kognitif. Selain itu, risiko masalah kesehatan pada bayi yang dilahirkan oleh ibu belum cukup umur antara lain BBLR (Berat Bayi Lahir Rendah), kelainan kongenital (cacat bawaan), hingga kematian janin. Kesedihan tentu akan dirasakan oleh pasangan jika buah hati nya mengalami masalah kesehatan yang dapat membahayakan nyawa janin tersebut. Tidak hanya dari segi kesehatan fisik, pernikahan dini berdampak negatif pada kesehatan mental atau kondisi psikologis pasangan tersebut beserta anaknya.

Ketidakstabilan emosi pada remaja dapat menimbulkan Kekerasan Dalam Rumah Tangga (KDRT). Kasus KDRT tak jarang menelan korban, seperti kasus yang terjadi di Indramayu tahun 2018 yang menyebabkan 1 korban meninggal dunia. Usia merupakan salah satu faktor yang memengaruhi kematangan emosional seseorang. Pada usia remaja, terjadi masa transisi dari masa kanak-kanak ke masa dewasa yang diawali dengan pubertas. Pada masa tersebut, selain proses kematangan fisik, terjadi proses kematangan sosial dan emosional. Seorang remaja telah mencapai kematangan emosional apabila pada akhir masa remaja (usia 1722 tahun), ia dapat mengontrol emosi, memahami diri sendiri, dan mampu menilai situasi secara kritis terlebih dahulu sebelum bereaksi secara emosional. Namun, pada pernikahan usia dini, laki-laki dan perempuan yang menikah belum memiliki kematangan emosional sehingga percekcokan, perceraian, dan kekerasan dalam rumah tangga rawan terjadi. Kekerasan dalam rumah tangga dapat menimbulkan trauma bahkan kematian bagi korban.

Menurut Dariyo dalam Mubasyorah (2016:

12) dampak pernikahan dini adalah timbulnya rasa cemas, stress, depresi, Sedangkan Nurkhasanah mengatakan bahwa pernikahan dini secara psikologis mengakibatkan trauma dalam jiwa remaja. Hal ini terjadi karena belum adana kesiapan mental seseorang untuk memiliki tanah. Kesiapan mental tentang pernikahan dini tidak akan bisa tercapai pada umur di bawah 20 tahun. Akibatnya, banyak terlihat jika remaja yang menikah pada usia muda (kurang 20 tahun) mengalami banyak gangguan psikologis seperti timbul rasa cemas, stress dan depresi ataupun trauma dalam jiwa remaja. Kemampuan seorang mengntrol emosi secara baik dapat tercapai pada usian di atas 21 tahun (2012: 19)
Selain itu, perceraian dan kekerasan dalam rumah tangga dapat berdampak pada psikologis anak dari pasangan tersebut. Anak akan merasa kurang mendapat perhatian dan kurang nyaman berada di rumah. Seperti yang telah diatur pada Undang-Undang No. 1 Tahun 1974 tentang Perkawinan, usia minimal perkawinan untuk lakilaki dan perempuan adalah 19 tahun. Namun, dari segi kesehatan, BKKBN (Badan Kependudukan dan Keluarga Berencana Nasional)

mengkampanyekan batasan usia yang ideal untuk menikah baik dari segi fisik dan mental, yaitu minimal 21 tahun bagi wanita dan 25 tahun pada pria. Oleh karena itu, sebaiknya pasangan memperhitungkan usia yang ideal untuk menikah, terutama dari segi kesehatan.

Mencermati dampak pernikahan dini dipaparkan di atas maka penting bagi kita untuk menyadarkan kepada masyarakat bahwa pernikahan dini perlu untuk diantisipasi atau diatasi dengan melakukan pemberdayaan anak dengan informasi, ketrampilan dan jaringan pendukung dengan kampanye berupa penyebaran informasi dan edukasi mengenai pernikahan anak, sekolah, hakhak, dan kesehatan seksual dan reproduksi dengan menggunakan media.

Meningkatkan akses dan kualitas pendidikan formal bagi anak, menawarkan dukungan ekonomi dan pemberian insentif pada anak dan keluarganya serta membuat dan mendukung kebijakaan terhadap pernikahan dini. Permasalahan yang dihadapi terkait dengan perkawinan dini di kalangan remaja sebagai berikut:

pertama, wanita muda biasanya kaget dengan rutinitas baru setelah menikah, bahkan tidak sedikit wanita yang melihat sang suami berubah, tidak lagi sempurna dan manis seperti saat pacaran. Wanita yang tidak bisa mengelola perubahan ini biasanya akan depresi dan tertekan, tidak bahagia dengan pernikahannya. Banyak wanita muda yang merasa mengorbankan masa mudanya untuk keluarga dan fokus membesarkan anak-anak, sedangkan teman sebaya mereka masih bisa bersenang-senang. Memasuki awal usia 20 tahun atau di awal usia 20 tahun, pemikiran wanita biasanya masih belum matang. Dia belum mengenal dirinya sendiri dan cenderung masih ikut arus. Belum memahami sebenarnya apa keinginan terbesar dalam hidupnya. Sering juga wanita jatuh cinta dan menikah dengan pria yang salah karena 
pemikirannya masih belum stabil. Merawat dan mengasuh anak bukan pekerjaan mudah, wanita yang menikah di usia muda seringkali mengorbankan karir untuk mengurus anaknya. Beberapa wanita merasa menyesal karena pengorbanan ini tidak menghasilkan materi.

Kedua, Seiring berjalannya waktu, wanita akan merasa telah mengorbankan banyak hal untuk suami dan anak-anaknya, dan itu terus terjadi hingga usia menua. Cinta yang awalnya menggebu jadi datar dan hanya sekedar formalitas saja. Tidak jarang pasangan yang menikah muda rentan perselingkuhan dan perceraian.

Ketiga, dampak terhadap kelangsungan perkawinan. Sebab perkawinan yang tidak disadari, Mempunyai dampak pada terjadinya perceraian (Lily Ahmad, 2008). Secara psikis anak juga belum siap dan mengerti tentang hubungan seks, sehingga akan menimbulkan truma psikis berkepanjangan dalam jiwa anak yang sulit dissebuhkan. Anak akan murung dan menyesali hidupnya yang berakhir pada perkawinan yang dia sedari tidak mengeti atas putusan hidupnya. Selain itu, ikatan perkawinan akan menghilangkan hak anak untuk memperoleh pendidikan (Wajib belajar 9 tahun), hak bermain dan menikmati waktu luangnya serta hak-hak lainnya yang melekat dala diri anak (Deputi, 2008). Dari Segi Sosial, fenomena sosial ini berkaitan dengan faktor sosial budaya dalam masyarakat yang menempatkan perempuan pada posisi yang rendah dan hanya diangggap pelengkap seks lakilaki saja (Deputi, 2008). Dari Segi Kebidanan, perempuan terlalu mudah untuk menikah di bawah umur 20Tahun beresiko terkena kangker rahim. Sebab pada usia remaja, sel-sel leher rahim belum matang (Dian Lutyfiyati, 2008: 12). Kegiatan pengabdian pada masyarakat ini dilakukan dengan tujuan agar khalayak sasaran, yaitu siswa SMAN 2 Gerung Kabupaten Lombok Barat dapat:

a. Memahami faktor-faktor penyebab terjadinya pernikahan dini di kalangan remaja

b. Memahami dampak fisik dan psikis pernikahan dini pada remaja.

c. Memahami solusi untuk mencegah pernikahan dini di kalangan remaja.

Kegiatan pengabdian ini bermanfaat untuk meningkatkan pengetahuan siswa SMAN 2 Gerung Kabupaten Lombok Barat tentang perkawinan dini. Selain itu kegiatan pengabdian ini memberikan manfaat kepada siswa meningkatkan pengetahuan tentang dampak perkawinan dini di kalangan remaja.

\section{Metode}

Pemecahan masalah dalam kegiatan pengabdian ini akan ditempuh dengan menggunakan pendekatan/metode sebagai berikut:

\section{Penyuluhan}

Metode penyuluhan digunakan untuk memberikan informasi atau pengetahuan dan pemahaman siswa tentang faktor-faktor penyebab perkawinan dini dan dampak perkawinan dini bagi siswa di SMA Negeri 2 Gerung Kabupaten Lombok Barat.

\section{Focus Group Discussion (FGD)}

Selain itu pendekatan/metode Focus Group Discussion (FGD) digunakan dalam rangka mencari solusi atau upaya untuk mencegah perkawinan dini bagi siswa di SMA Negeri 2 Gerung Kabupaten Lombok Barat.

Target luaran setelah kegiatan pengabdian ini selesai adalah:

1. Terpolanya pengetahuan dan pemahaman tentang faktor-faktor penyebab terjadi pernikah dini di kalangan remaja.

2. Terpolanya pengetahuan dan penamahan tentang dampak atau bahaya perkawinan dini di kalangan remaja.

3. Terpolanya solusi atau upaya untuk mencegah terjadinya perkawinan dini di kalangan remaja.

\section{Hasil dan Pembahasan}

Kegiatan pengabdian kepada masyarakat di SMA Negeri 2 Lembar Kabupaten Lombok Barat dilaksanakan sejak 19 Juli sampai dengan tanggal 30 November 2020 dalam bentuk penyuluhan dan Focus Group Discussion (FGD). Kegiatan tersebut dapat dilaksanakan dengan lancar sesuai dengan jadwal yang direncanakan. Untuk lebih jelasnya mengenai pelaksanaan kegiatan dimaksud dan hasil yang dicapai dapat dicermati dari setiap kegiatan yang telah dilaksanakan sebagai berikut:

\section{Kegiatan Perencanaan/persiapan}

Kegiatan yang dilaksanakan pada tahap perencanaan/persiapan meliputi:

a Koordinasi dengan Kepala SMA Negeri 2
Gerung 
Kegiatan ini diawali dengan pemberitahuan kepada Kepala SMA Negeri 2 Gerung Ibu Sylvani Kadir, S.Pd mengenai kegiatan pelaksanaan pengabdian dengan tema "Penyuluhan Tentang Dampak Perkawinan Dini Bagi Remaja Bahaya Penyalahgunaan Narkoba Bagi Siswa Di SMA Negeri 2 Gerung Kabupaten Lombok Barat". Rencana kegiatan tersebut disambut dengan baik oleh Kepala SMA Negeri 2 Gerung dan selanjutnya merekomendasikan kepada Wakil Kepala Sekolah Urusan Kesiswaan Bapak M. Anwar, S.Pd, untuk membicarakan lebih lanjut mengenai teknis pelaksanaan kegiatan pengabdian.

\section{b Rekrutmen peserta}

Rekrutmen peserta dilakukan dalam rangka memperoleh sejumlah peserta yang akan dilibatkan dalam kegiatan pengabdian kepada masyarakat yaitu siswa-siswa SMA Negeri 2 Kelas II dan III. Mengingat keterbatasan anggaran dalam pelaksanaan pengabdian masyarakat ini, maka tim pengabdian membatasi jumlah peserta yaitu 87 orang yang terdiri dari perwakilan Kelas, I, II dan III SMA Negeri 2 Gerung.

\section{c Identifikasi Kebutuhan}

Identifikasi kebutuhan merupakan tahapan kegiatan persiapan yang tidak kalah penting dalam kegiatan pengabdian kepada masyarakat. Hal ini disebabkan ketersediaan berbagai kebutuhan yang diperlukan menjadi bagian yang sangat penting untuk dapat terlaksananya kegiatan dengan lancar. Berbagai kebutuhan yang teridentifikasi dalam kegiatan pengabdian tersebut ada yang disediakan oleh pihak SMA Negeri 2 Gerung dan pihak tim pengabdian Universitas Mataram. Adapun berbagai kebutuhan yang disediakan oleh sekolah, diantaranya: (1) tempat kegiatan, yaitu di Aula SMA Negeri 2 Gerung (2) kursi dan meja narasumber dan peserta (3) seperangkat alat pengeras suara. Sedangkan kebutuhan lainnya disiapkan oleh Tim Pengabdian Universitas Mataram diantaranya: (1) konsumsi dan uang transport (2) LCD.

\section{Kegiatan Pelaksanaan}

Kegiatan yang dilaksanakan adalah penyuluhan dan FGD. Penyuluhan dilaksanakan dalam rangka memberikan informasi kepada siswa SMA Negeri 2 Gerung terkait Penyuluhan Dampak Perkawinan Dini Bagi Remaja Bagi Siswa Di SMA Negeri 2 Gerung Kabupaten Lombok Barat".
Kegiatan penyuluhan ini memberikan manfaat yang positif dalam rangka meningkatkan pengetahuan siswa tentang Dampak Perkawinan Dini Bagi Remaja Di SMA Negeri 2 Gerung Kabupaten Lombok Barat, sehingga akan dapat mencegah terjadinya perkawinan dini di kalangan siswa. Kemudian dapat mengetahui faktor-faktor dan dampak terjadinya perkawinan dini bagi siswa. Selain itu kegiatan pengabdian ini memberikan manfaat kepada siswa meningkatkan pengetahuan tentang upaya yang ditempuh untuk mencegah terjadinya perkawinan dini di kalangan siswa.

Sementara itu FGD dilaksanakan dalam rangka menjaring berbagai masukan atau pandangan terkait upaya yang ditempuh untuk mencegah terjadinya perkawinan dini di kalangan siswa. Dalam hal ini muncul permasalahan yang urgen seperti, faktor-faktor yang mempengaruhi perkawinan dini di kalangan siswa dan upaya yang ditempuh untuk mencegah terjadinya perkawinan dini di kalangan siswa. Untuk lebih jelasnya mengenai pelaksanaan kedua kegiatan tersebut (penyuluhan dan FGD) dapat dijelaskan sebagai berikut:

\section{a Penyuluhan}

Pelaksanaan kegiatan dibuka oleh Kepala SMA Negeri 2 Gerung sekaligus memberikan sambutan. Kemudian dilanjutkan dengan penyampaian materi penyuluhan oleh tim pengabdian Universitas Mataram sebagai berikut:

A. Pernikahan Dini ((Disampaikan Oleh: I Nengah Agus Tripayana, S.Pd., M.Pd))

\section{Konsep Pernikahan Dini}

Periode usia remaja merupakan periode transisi atau peralihan, remaja mengalami masa peralihan. Tidak ada anak perempuan dan anak laki-laki yang tidak melewati masa remaja. Menurut Darajat (Al-Ghifari, 2004: 24) "Remaja itu sendiri adalah anak yang dalam masa peralihan antara masa anak-anak ke masa dewasa serta mengalami perubahan-perubahan yang cepat dalam segala bidang. Mereka bukan lagi anak, baik bentuk badan, sikap, dan cara berpikir serta bertindak namun bukan pula orang dewasa yang telah matang".

Secara umum pernikahan usia muda adalah pernikahan yang dilakukan oleh seorang laki-laki dan seorang wanita yang umur keduanya masih dibawah batasan minimum 
yang diatur oleh Undang-Undang (Rohmah, 2009). Secara hukum, disebutkan pada Undangundang perkawinan tahun 1974 pasal 7 ayat 1 bahwa perkawinan hanya diizinkan jika pihak pria sudah mencapai umur 19 (sembilan belas) tahun dan pihak wanita sudah mencapai umur 16 (enam belas) tahun.

Dalam Pasal 6 ayat 2 UU No. 1 Tahun 1974 juga dinyatakan bahwa untuk melangsungkan suatu perkawinan seseorang yang belum mencapai umur 21 tahun harus mendapat ijin dari kedua orang tua. Seperti halnya juga telah dijelaskan dalam UU Republik Indonesia Nomor 1 pasal 1 tahun 1974 tentang perkawinan, yang menyatakan bahwa perkawinan adalah ikatan lahir batin antara seorang pria dengan wanita sebagai suami isteri dengan tujuan membentuk keluarga yang bahagia dan kekal berdasarkan Ketuhanan Yang Maha Esa.

Dengan penjelasan diatas maka perkawinan usia muda dapat didefenisikan sebagai ikatan lahir batin antara seorang lakilaki dengan perempuan sebagai suami isteri di usia yang masih muda/remaja. Sehubungan dengan perkawinan usia muda, maka ada baiknya kita terlebih dahulu melihat pengertian daripada remaja (dalam hal ini yang dimaksud rentangan usianya). Golongan remaja muda adalah para gadis berusia 14 sampai 16 tahun, inipun sangat tergantung pada kematangan secara fisik, sehingga penyimpanganpenyimpangan secara kasuistik pasti ada. Dan bagi laki-laki yang disebut remaja muda berusia 14 tahun sampai 16 tahun.

\section{Pengertian Pernikahan}

Secara etimologi kata nikah (kawin) mempunyai beberapa arti yaitu berkumpul, bersatu, bersetubuh, dan akad. Adapun kata nikah secara terminology, menurut imam syafieci nikah yaitu akad yang dennganya menjadikan halal hubungan seksual antara pria dengan wanita . menurut imam Hanafi ni kah yaitu akad yang menjadikan halal hubungan seksual sebagais uami antara seorang pria dengan wanita. Menurut imam malik nikah adalah akad yang yang mengandung ketentuan hukum semata-mata untuk membolehkan

wathi'(bersetubuh), bersenang-senang, dan menikmati apa yang ada dalam diri wanita ang boleh menikah denganya . menurut imam hanafi nikah adalah akad dengan menggunkan lafaz nikah atau tazwij untuk membolehkan manfaat, bersenang-senang dengan wanita.

Pernikahan juga di bahas dan diatur oleh undang-undang, adapun UndangUndang yang membahas mengenai pernikahan yaitu UndangUndang No 1 tahun 1974, di dalam undangundang tersebut di ayat 1 menerangkan perkawinan adalah ikatan lahir bathin antara seorang pria dan wanita wanitasebagai suami istri dengan tujuan membentuk keluarga (rumah tangga) yang bahagia dan kekal berdasarkan ketuhann Yang Masa Esa. Dan pernikahan menurut KHI adalah akad yang sangat atau miitsaaqan gholiidhan untuk untuk menaati perintah Allah dan melaksanakan ibadah yang bertujuan untuk mewujudkan kehidupan rumah tangga yang sakinah, mawadah, dan rahmah.

Dari penegrtian-pengertian diatas dapat diambil pengertian bahwa pernikahan adalah akad yang sangat kuat yang mengadung ketentuan- ketentuan hukum kebolehan hubungan seksual dengan lafadz nikah dan katakata yang semakna dengan untuk membina rumah tangga yangyang sakinah dan untuk menaati perintah Allah swt dan melakukanya merupakan ibadah.

B. Syarat dan Rukun Nikah ((Disampaikan oleh: Ahmad Fauzan, S,.Pd., M.Pd)

Sebelum melangkah ke jenjang pernikahan maka terlebih dahulu harus di perhatikan hal-hal yang mendasar dari terlaksananya kegiatan tersebut, yaitu dilengkapi syarat-syarat serta rukunrukun dari pernikahan tersebut. Untuk memperoleh gambaran yang jelas mengenai syarat dan rukun perkawinan, akan dijelaskan berikut, syarat-syarat perkawinan mengikuti rukunya seperti dikemukakan Kholil Rahman.

a. Calon mempelai pria, syarat-syaratnya:

1. Beragam islam

2. Laki-laki

3. Jelas orangnya

4. Dapat memberikan persetujuan.

5. Tidak terdapat halangan perkawinan.

b. Calon mempelai wanita, syarat-syaratnya:

1. Bergama

2. Perempuan

3. Jelas orangnya

4. Dapat diminta persetujuan 
5. Tidak terdapat halangan kawin.

c. Wali nikah, syarat-syaratnya:

1. Laki-laki

2. Dewasa

3. Mempunya hak perwalian

4. Tidak terdapat halangan perkawinan

d. Saksi nikah, syarat-syaratnya:

1. Minimal dua orang laki-laki

2. Hadir dalam ijab qabul

3. Dapat mengerti maksud akad

4. Islam

5. Dewasa

e. Ijab qabul, syarat-syaratnya:

1. Adanya pernyataan mengawinkan dari wali

2. Adanya pernyataan menerima dari calon mempelai pria

3. Memakai kata-kata nikah

4. Antara ijab dan qabul bersambungan

5. Antar ijab dan qabul jelas maknanya

6. Orang yang terkait ijab qabul tidak sedang ihram

7. Majelis ijab qabul minimal harus dihadiri empat orang

Rukun dan syarat perkawinan tersebut wajib di penuhi, apabila tidak terpenuhi maka perkawinan yang dilangsungkan tidak sah, jadi semua syarat dan rukun yang arus ada dalam melangsungkan perkawinan haruslah terpenuhi supaya pernikahan tersebut tidak disebut nikah fasid yaitu nikah yang tidak memenuhi syaratnya sedangkan nikah bathil adalah nikah yang tidak terpenuhi rukunya.

\section{Hukum Nikah}

Nikah ditinjau dari segi hukum syar"i ada lima macam, secara rinci jumhur ulama menyatakan hukum perkawinan itu dengan melihat keadaan orang-orang tertentu:

a. Sunnah bagi orang-orang yang telah berkeinginan untuk menikah, telah pantas untuk menikah dan dia telah mempunyai perlrngkapan untuk melangsungkan perkawinan.

b. Makruh bagi orang-orang yang belum pantas untuk menikah, belum berkeinginan untuk menikah, sedangkan perbekalan untuk perkawinan juga belum ada. Begitu pula ia telah mempunyai perlengkapan untuk perkawinan, namun fisiknya mengalami cacat impoten, berpenyakitan tetap, tua Bangka dan kekurangan fisik lainnya.

c. Wajib bagi orang-orang yang telah pantas untuk menikah, berkeinginan untuk menikah dan memiliki perlengkapan untuk menikah, ia khawatir akan terjerumus ke tempat maksiat kalau ia tidak menikah.

d. Haram bagi orang-orang yang tidak akan dapat memenuhi ketentuan syara ${ }^{\text {ee }}$ untuk melakukan perkawinan atau ia yakin perkawinan itu tidak akan memcapai tujuan syara ${ }^{e e}$, sedangkan dia meyakini perkawinan itu akan merusak kehidupan pasangannya.

e. Mubah, bagi orang-orang yang pada dasarnya belum ada dorongan untuk menikah dan perkwaninan itu tidak akan mendatangkan kemudaratan apa-apa kepada siapapun.

2. Dasar Hukum Perkawinan Menurut Hukum Positif dan Hukum Islam

Urusan pernikahan juga diatur oleh Negara bertujuan untuk ketertiban administrasi dan mengatur pernikahan yang dilakukan di suatu Negara tersebut, begitu pula dengan Indonesia mempunyai aturan atau undang-undang yang mengatur tentang pernikahan dan itu dijadikan dasar hukum pernikahan menururt hukum positif, adapun dasar hukum perkawinan yang berlaku sekarang ini anatra lain:

a. Buku I dari kitab Undang-undang Hukum Perdata, yaitu Bab IV sampai dengan Bab IX.

b. Undang-undang No. 1 Tahun 1974 tentang perkawinan.

c. Undang-undang No. 7 Tahun 1989 tentang Peradilan Agama.

d. Peraturan Pemerintah No. 9 Tahun 11974 tentang pelaksanaan UU No. 1 tahun 1974 tentang perkawinan.

e. Peraturan Pemerintah No. 45 Tahun 1990 tentang perubahan dan tambahan Peraturan Pemerintah No. 10 tahun 1983 tentang izin perkawinan dan perceraian bagi pegai negeri sipil.

f. Instuksi Presiden No. 1 tahun 1991 tentang Kompilasi Hukum Islam di Indonesia (pasal 1$170 \mathrm{KHI})$.

C. Faktor-Faktor Penyebab Pernikahan Usia Muda (Disampaikan Oleh: Hj. Yuliatin, S.Pd., M.H) 
Jayadiningrat (dalam Suparman, 2000: 45) menyatakan bahwa salah satu penyebab utama terjadinya pernikahan usia muda tidak adanya pengertian mengenai pernikahan serta masih adanya kepercayaan mempertahankan tradisi yang berkembang dalam masyarakat, akibatnya pernikahan usia muda dikalangan anak perempuan masih berlangsung. Umumnya tradisi menikah muda ini terjadi di pedesaan. Hal ini karena kurangnya pengetahuan masyarakat mengenai pernikahan usia muda serta dampaknya terhadap pendidikan anak perempuan. Masyarakat pedesaan masih percaya dengan tradisi nenek moyang yang diwariskan secara turun menurun. Banyak faktor yang menyebabkan terjadinya pernikahan usia muda salah satunya sosial budaya. Para orang tua dipedesaan umumnya masih berpikiran bahwa anak perempuan tidak perlu sekolah jauh-jauh apalagi sampai kuliah, yang penting anak itu bisa baca dan menulis itu sudah cukup bagi mereka dan setelah itu anak perempuan itu sudah bisa menikah, orang tua tidak pernah mempertimbangkan umur anak perempuan mereka terpenting anak perempuan mereka bisa memasak dan mengurus suami. Karena meskipun pendidikan anak perempuan mereka tinggi pada akhirnya akan kembali ke dapur juga.

Hal tersebut yang mendorong orang tua menikahkan anak mereka dengan alasan takut anaknya menjadi perawan tua. Pandangan orang tua mengenai anak mereka yang tidak segera menikah menyebabkan anak merasa terkucil dari temantemannya karena perbedaan status yang mereka sandang antara yang belum menikah dengan mereka yang sudah menikah. Akibatnya anak perempuan memutuskan untuk segera menikah. Meskipun terkedang tidak hanya lingkungan yang berpengaruh justru orang tua mereka yang terburuburu menikahkan anak perempuannya dengan alasan adat, tradisi dan budaya masyarakat setempat. Orang tua mereka mengatakan jika maka perempuan tidak segera dinikahkan, mereka hanya akan menjadi beban mental orang tua.

\section{Faktor Budaya}

Kebudayaan berasal dari bahasa Sansekerta buddayah, yang merupakan bentuk jamak dari buddhi, berarti budi atau akal. Dengan demikian, kebudayaan berati hal-hal yang bersangkutan dangan akal. Adapun ahli Antropologi yang merumuskan definisi tentang kebudayaan secara sistematis dan ilmiah adalah Taylor, yang menulis bukunya "Primitive Culture", bahwa kebudayaan adalah keseluruhan yang kompleks yang didalamnya terkandung ilmu pengetahuan, kepercayaan, kesenian, moral, hukum, adat-istiadat, tradisi, yang didapat oleh manusia sebagai anggota masyarakat (Ranjabar, 2006).

Syafiq Hasyim dalam Jannah (2012) menyebutkan bahwa dalam konteks Indonesia pernikahan lebih condong diartikan sebagai kewajiban sosial dari pada manifestasi kehendak bebas setiap individu. Secara umum, dalam masyarakat yang pola hubungannya bersifat tradisional, pernikahan dipersepsikan sebagai suatu "keharusan sosial" yang merupakan bagian dari warisan tradisi dan dianggap sakral. Sedangkan dalam masyarakat rasional modern, perkawinan lebih dianggap sebagai kontrak sosial, dan karenanya pernikahan sering merupakan sebuah pilihan. Cara pandang tradisional terhadap perkawinan sebagai kewajiban sosial ini, tampaknya memiliki kontribusi yang cukup besar terhadap fenomena kawin muda yang terjadi di Indonesia dan dijadikan budaya yang sampai saat ini masih berkembang di Indonesia terutama di pedesaan.

Goodenough (dalam Kalangie, 1994) mengemukakan bahwa kebudayaan adalah suatu sistem kognitif, yaitu suatu sistem yang terdiri dari pengetahuan, kepercayaan dan nilai-nilai yang berada dalam pikiran-pikiran anggota individual masyarakat. Kebudayaan berada pada tatanan kenyataan yang idesional atau merupakan kelengkapan mental yang oleh anggota-anggota masyarakat dipergunakan dalam proses orientasi, transaksi, pertemuan, perumusan, gagasan, penggolongan dan penafsiran perilaku sosial yang nyata dalam masyarakat.

Dalam Antropologi, budaya adalah pola perilaku dan pemikiran masyarakat yang hidup dalam kelompok sosial belajar, mencipta dan berbagi (Microsoft Encarta Reference Library, 2005). Budaya membedakan kelompok manusia yang satu dengan yang lainnya. Menurut Ariel Heryanto (2000), kebudayaan bukan dipandang bukan sebagai suatu realitas kebendaan tapi persepsi pemahaman untuk melihat, menangkap dan mencerna realitas. Faktor budaya dapat memberikan dampak positif dan negatif terhadap individu tergantung pada jenis budayanya. Hal ini tergantung dari bagaimana individu dapat membedakan dampak tersebut. 
Budaya yang melekat pada diri orang tua menyebabkan orang tua menikahkan anak perempuannya pada usia muda. Dalam budaya ini terdapat dua indikator yang mempengaruhi orang tua menikahkan anak perempuannya diusia muda antara lain:

a. Lingkungan dalam masyarakat yang sangat berpengaruh terhadap terjadinya suatu kebiasaan atau tradisi. Hal ini pun terjadi dimasyarakat Desa Sumberdanti dimana terdapat tradisi menikahkan anak perempuannya diusia muda.

b. Adanya anggapan dalam masyarakat bahwa anak perempuan yang telah berusia remaja dan belum menikah maka akan dianggap perawan tua dan tidak laku. Hal ini juga yang menyebabkan orang tua segera menikahkan anaknya.

\section{Tradisi}

Tradisi merupakan "the body of knowledge, costum and other Transmitted down through generations" (Webster's Pocket: 2002) artinya "Pengetahuan, kebiasaan, dan sebagainya yang ditransmisikan antar generasi" (Kamus Websters: 2002). Termasuk unsur-unsur budaya immaterial seperti cara berpikir, kepercayaan, gaya, atau filsafat. Tradisi berasal dari kata tradere yang artinya menyerahkan dan mengirimkan. Jadi, tradisi terletak bukan pada antar generasi melainkan transmisi.

Lakhani (2009: 27) menjelaskan, tradisi (dengan huruf " $\mathrm{t}$ "e kecil) berbeda dengan arti Tradisi (dengan " $T$ " besar). Tradisi secara fundamental merupakan etiket kebiasaan, atau cara konvensional melakukan atau melihat sesuatu; sementara dalam arti khusus, Tradisi merupakan pandang dunia, pandangan masa lalu, dan cara keberadaan.

Banyak tokoh yang mendefinisikan arti dari tradisi. Tradisi menjadi pandangan masa lalu mengenai hal tertentu. Seperti halnya dengan beberapa tradisi yang berkembang di Indonesia. Memang kehidupan saat ini mulai banyak mengalami perubahan namun berbeda dengan beberapa masyarakat daerah yang ada di pedesaan. Masih banyak masyarakat yang berpegang teguh pada tradisi yang mereka anggap sebagai warisan nenek moyang mereka dan beranggapan bahwa apabila memang seharusnya kebiasaan nenek moyang harus dipertahankan.

Pandangan tersebut masih dipertahankan oleh masyarakat di Pulau Jawa khususnya di Desa
Sumberdanti Kecamatan Sukowono Kabupaten Jember. Masyarakat didesa ini beranggapan bahwa memang seharusnya tradisi nenek moyang dipertahankan dan tidak akan berubah oleh perkembangan jaman. Kurangnya pengetahuan mengenai tadisi menyebabkan masyarakat didesa ini belum terlalu terpengaruh oleh perkembangan jaman. Mayoritas masyarakat di desa ini masih mempertahankan tradisi salah satunya tradisi menikah muda. Tradisi menikah muda di desa ini di anggap sebagai sesuatu yang wajar. Para orang tua menikahkan anak mereka pada usia yang relatif muda antara 14-16 tahun. Mereka yang memiliki anak perempuan sudah biasa menikahkan anak perempuannya pada usia 14-16 tahun tanpa memikirkan bahwa pada rentang usia tersebut, anak mereka seharusnya mendapatkan pendidikan. Namun karena mengikuti tradisi, para orang tua memilih untuk menikahkan anak perempuan mereka dengan jalan perjodohan tanpa adanya musyawarah dengan anak perempuannya.

Akibatnya anak perempuan didesa ini tidak bisa melanjutkan pendidikan formal hanya karena mengikuti keinginan orang tua mereka. Kepatuhan terhadap orang tua merupakan kewajiban setiap anak, anak perempuan didesa ini terpaksa mengikuti keinginan orang tua mereka sekalipun mereka ingin melanjutkan pendidikan.

\section{Adat Istiadat}

Adat-istiadat adalah dalil atau ajaran mengenai bagaimana orang bertingkah laku dalam masyarakat. Adat dalam pengertian ini berfungsi sebagai dasar pembangunan hukum adat positif yang lain. Istilah adat seringkali di artikan sebagai kebiasaan,namun pada dasarnya memiliki arti yang sama, jika mendengar adat-istiadat biasanya aktivitas seseorang dalam masyarakat terjadi secara berulang-ulang dalam jangka waktu tertentu. Suatu adat-istiadat yang hidup dan berkembang dalam masyarakat dan dapat berubah dan diakui sebagai hukum. Pandangan bahwa agama memberi pengaruh terhadap berkembangnya adat- istiadat bertentangan dengan konsepsi Van Den Berg dengan teori reception in complex menurut pandangan adat istiadat suatu tradisi dan kebiasaan nenek moyang kita yang sampai sekarang masih dipertahankan untuk mengenang nenek moyang kita juga sebagai bentuk keanekaragaman budaya. 
Adat-istiadat seringkali dikaitkan dengan istilah adat kebiasaan yang berkembang dalam masyarakat yang terjadi berulang-ulang sehingga membentuk pola dalam masyarakat. Adat antara daerah satu dengan yang lain berbeda yang membentuk hukum adat seperti pelabelan (stereotip), omongan miring dalam masyarakat. Adat-istiadat bersifat tidak tertulis dan terpelihara secara turun- menurun sehingga mengakar dalam masyarakat meskipun adat-istiadat tersebut tercampur oleh kepercayaan nenek moyang. Seperti halnya tradisi menikah muda yang terjadi di Desa Sumberdanti Kecamatan Sukowono Kabupaten Jember, apabila para orang tua tidak segera menikahkan anak perempuan mereka yang telah baligh serta dilihat secara fisik siap untuk dinikahkan, maka anak perempuan tersebut akan di anggap tidak laku dan menjadi perawan tua.

Dapat disimpulkan bahwa adat istiadat sama halnya dengan tradisi yaitu kebiasaan yang berkembang dalam masyarakat dan terjadi berulang dalam kurun waktu tertentu. Adat-istiadat merupakan warisan turun-temurun nenek moyang yang memang apabila dilanggar, individu akan mendapatkan hukum adat. Perkawinan dibawah umur seringkali dikaitkan dengan dorongan kultural dalam satu komunitas yang memposisikan perempuan sebagai kelaas dua. Sehingga masyarakat seperti di Desa Sumberdanti menghindari stigma perawan tua dengan mempercepat pernikahan anak perempuan mereka.

\section{Faktor Rendahnya Tingkat Pendidikan}

Pendidikan secara umum adalah segala upaya yang dilakukan untuk mempengaruhi orang lain baik individu, kelompok atau masyarakat. Sehingga mereka melakukan apa yang diharapkan pelaku pendidikan (Soekidjo Notoadmijo dalam T.O Ihromi, 2003: 16). Sedangkan menurut Nasution (2010) pendidikan adalah interaksi individu dengan anggota masyarakat, yang berkaitan dengan perubahan dan perkembangan yang berhubungan dengan pengetahuan, sikap, kepercayaan, dan keterampilan. Bagi seorang individu, pendidikan adalah suatu hal yang penting untuk dimiliki karena dengan pendidikan individu akan semakin berkembang. Menurut Ki Hajar Dewantara (dalam Salim, 2003: 128) pendidikan harus dilakukan melalui 3 lingkungan meliputi persekolahan (formal), pendidikan luar sekolah (nonoformal), dan pendidikan keluarga (informal).
Salah satu lingkumgan pendidikan yang dipilih orang tua adalah sekolah atau pendidikan formal.

Pendidikan sekolah atau formal memberikan peranan penting terhadap sosialisasi individu dalam masyarakat sehingga dapat menjadi individu yang sesuai dengan harapan masyarakat. Dalam artian pendidikan formal khususnya sekolah dapat menjadi motor penggerak terbentuknya individu yang memiliki karakter yang sesuai dengan nilai yang tertanam dalam masyarakat. Selain itu pendidikan formal dapat menjadi mobilitas bagi individu untuk dapat berinteraksi dengan nilai-nilai yang terbentuk dalam masyarakat. Jenjang pendidikan formal ini bisa ditempuh mulai dari pendidikan SD sampai perguruan tinggi.

Karena pendidikan nonformal disini merupakan sebuah pelayanan pendidikan yang tidak dibatasi dengan waktu, usia, jenis kelamin, ras (suku, keturunan), kondisi sosio-kultural, ekonomi, agama dan lain-lain. Pendidikan informal merupakan pendidikan yang diterima individu di dalam keluarga inti. Berkaitan dengan pendidikan penanaman nilai-nilai, norma serta pendidikan yang berkaitan dengan pengenalan nilai sosio-kultural di dalam keluarga individu. Pendidikan informal sangat berpengatuh terhadap pembentukan nilai dalam diri individu berkaitan dengan pengenalan nilai agama, nilai dalam masyarakat tentan bagaimana berintegrasi dalam masyarakat dengan baik dan bisa menyesuaikan diri dengan masyarakat dilingkungannya.

Dari pengertian di atas dapat disimpulkan Pendidikan merupakan usaha sadar yang dilakukan seluruh aspek yang ada dikehidupan kita, baik orang terdekat, masyarakat maupun lembaga yang ada, baik yang terjadi secara formal, nonformal atau informal dengan mengubah kebiasaan-kebiasaan tidak baik menjadi kebiasaan yang baik yang terjadi sepanjang hidup kita untuk memperbaiki kualitas diri menjadi lebih baik dan mampu menjawab tantangan masa depan yang bertalian dengan sosio-kultural, kepercayaan, pengetahuan, sikap, dan kebiasaan yang berkembang dalam masyarakat. Berdasarkan UU No. 20/2003 tentang Sistem Pendidikan Nasional, jalur pendidikan terdiri atas pendidikan formal, nonformal dan informal.Jenjang pendidikan formal terdiri atas pendidikan dasar, menengah, dan tinggi. 
Dalam konteks pendidikan, penelitian Landung dkk (2009) menjelaskan bahwa rendahnya tingkat pendidikan orang tua, menyebabkan adanya kecenderungan mengawinkan anaknya yang masih di bawah umur. Hal tersebut berkaitan dengan rendahnya tingkat pemahaman dan pengetahuan orangtua terkait konsep remaja gadis. Pada masyarakat pedesaan umumnya terdapat suatu nilai dan norma yang menganggap bahwa jika suatu keluarga memiliki seorang remaja gadis yang sudah dewasa namun belum juga menikah dianggap sebagai aib keluarga, sehingga orang tua lebih memilih untuk mempercepat pernikahan anak perempuannya.

\section{Faktor Rendahnya Tingkat Ekonomi}

Pernikahan usia muda yang terjadi disebabkan karena alasan mengurangi kebutuhan ekonomi keluarga. Faktor ini berhubungan dengan rendahnya tingkat ekonomi keluarga. Orang tua tidak memiliki kemampuan untuk memenuhi kebutuhan keluarga sehingga orangtua memilih untuk mempercepat pernikahan anaknya, terlebih bagi anak perempuan sehingga dapat mengurangi pemenuhan kebutuhan keluarga (Landung dkk, 2009). Sejalan dengan hal itu, Jannah (2012) menjelaskan dalam penelitiannya bahwa para orang tua yang menikahkan anaknya pada usia muda mengganggap bahwa dengan menikahkan anaknya, maka beban ekonomi keluarga akan berkurang satu. Hal ini disebabkan jika anak sudah menikah, maka akan menjadi tanggung jawab suaminya. Bahkan para orang tua juga berharap jika anaknya sudah menikah, maka akan dapat membantu kehidupan orang tuanya.

Jika dilihat dari segi ekonomi, masyarakat di Desa Sumberdanti Masih berada dalam kondisi yang tidak baik. Hal ini dilihat dari mata pencaharian mereka sebagai besar masyarakatnya bekerja sebagai buruh tani, buruh gudang, pedagang dipasar dan lain-lain. Hal tersebut yang menjadi penyebab orang tua menikahkan anak perempuannya diusia remaja. Orang tua menganggap bahwa apabila anak perempuan mereka telah menikah maka beban dalam keluarga akan berkurang karena anaknya telah memiliki suami yang akan bertanggung jawab terhadap kehidupan anak perempuannya.

Dengan menikahkan anak perempuannya, orang tua berharap anaknya dapat membantu perekonomian orang tua dalam memenuhi kebutuhan sehari-harinya. Tetapi pada kenyataannnya kondisi suami anak perempuannya tidak jauh berbeda dengan kondisi orang tuanya. Menurut Kasmiati dalam (www. suarantb.com) mengemukakan bahwa dalam lapisan masyarakat tertentu, pernikahan usia muda itu akhirnya menjadi sebuah budaya yang dibarengi dengan persoalanpersoalan ekonomi keluarga. Ada kecenderungan orang tua memiliki anak perempuan usia 16 tahun kemudian cenderung menikahkan anaknya hanya untuk meringankan ekonomi keluarga. Masalah itu merupakan akumulasi dari persoalan sosial yang dialami warga pedesaan khususnya. Lemahnya daya kreativitas yang membuat tidak adanya satu aktivitas positif yang mampu mendorong mereka memenuhi kebutuhan pendidikan untuk meningkatkan SDM. Akhirnya, pernikahan seringkali menjadi pilihan terakhir.

\section{Dampak Negatif Pernikahan Dini (Disampaikan Oleh: M. Mabrur Haslan, S.Pd., M. Hum)}

1. Wanita muda biasanya kaget dengan rutinitas baru setelah menikah, bahkan tidak sedikit wanita yang melihat sang suami berubah, tidak lagi sempurna dan manis seperti saat pacaran. Wanita yang tidak bisa mengelola perubahan ini biasanya akan depresi dan tertekan, tidak bahagia dengan pernikahannya. Banyak wanita muda yang merasa mengorbankan masa mudanya untuk keluarga dan fokus membesarkan anak-anak, sedangkan teman sebaya mereka masih bisa bersenang-senang.

2. Memasuki awal usia 20 tahun atau di awal usia 20 tahun, pemikiran wanita biasanya masih belum matang. Dia belum mengenal dirinya sendiri dan cenderung masih ikut arus. Belum memahami sebenarnya apa keinginan terbesar dalam hidupnya. Sering juga wanita jatuh cinta dan menikah dengan pria yang salah karena pemikirannya masih belum stabil. Merawat dan mengasuh anak bukan pekerjaan mudah, wanita yang menikah di usia muda seringkali mengorbankan karir untuk mengurus anaknya. Beberapa wanita merasa menyesal karena pengorbanan ini tidak menghasilkan materi.

3. Seiring berjalannya waktu, wanita akan merasa telah mengorbankan banyak hal untuk suami dan anak-anaknya, dan itu terus terjadi hingga usia menua. Cinta yang awalnya menggebu jadi datar dan hanya sekedar formalitas saja. Tidak 
jarang pasangan yang menikah muda rentan perselingkuhan dan perceraian.

4. Dampak dari pernikahan dini bukan hanya dari dampak kesehatan, Tetapi punya dampak juga terhadap kelangsungan perkawinan. Sebab perkawinan yang tidak disadari, Mempunyai dampak pada terjadinya perceraian(Lily Ahmad, 2008). Secara psikis anak juga belum siap dan mengerti tentang hubungan seks, sehingga akan menimbulkan truma psikis berkepanjangan dalam jiwa anak yang sulit dissebuhkan. Anak akan murung dan menyesali hidupnya yang berakhir pada perkawinan yang dia sedari tidak mengeti atas putusan hidupnya. Selain itu, ikatan perkawinan akan menghilangkan hak anak untuk memperoleh pendidikan (Wajib belajar 9 Tahun), hak bermain dan menikmati waktu luangnya serta hak-hak lainnya yang melekat dala diri anak (Deputi, 2008). Dari Segi Sosial, fenomena sosial ini berkaitan dengan faktor sosial budaya dalam masyarakat yang menempatkan perempuan pada posisi yang rendah dan hanya diangggap pelengkap seks laki-laki saja (Deputi, 2008).

Dari Segi Kebidanan, perempuan terlalu mudah untuk menikah di bawah umur 20Tahun beresiko terkena kangker rahim. Sebab pada usia remaja, sel-sel leher rahim belum matang (Dian Lutyfiyati, 2008).

5. Dampak terhadap hukum. Adanya pelanggaran terhadap 3 Undang-undang di negara kita yaitu:

a UU No.1 tahun 1974 tentang Perkawinan Pasal 7 ayat (1) Perkawinan hanya diizinkan jika pihak pria sudah mencapai umur 19 tahun dan pihak wanita sudah mencapai umur 16 tahun. Pasal 6 ayat (2) Untuk melangsungkan perkawinan seorang yang belum mencapai umur 21 tahun harus mendapat izin kedua orang tua.

b UU No. 23 tahun 2002 tentang Perlindungan Anak. Pasal 26 (1) Orang tua berkewajiban dan bertanggung jawab untuk:

a. Mengasuh, memelihara, mendidik dan melindungi anak

b. Menumbuh kembangkan anak sesuai dengan kemampuan, dan bakat

c. mencegah terjadinya perkawinan pada usia anak-anak. c UU No.21 tahun 2007 tentang PTPPO Patut ditengarai adanya penjualan /pemindah tanganan antara kyai dan orang tua anak yang mengharapkan imbalan tertentu dari perkawinan tersebut. Amanat Undangundang tersebut di atas bertujuan melindungi anak, agar anak tetap memperoleh haknya untuk hidup, tumbuh dan berkembang serta terlindungi dari perbuatan kekerasan, eksploitasi dan diskriminasi. Sungguh disayangkan apabila ada orang atau orang tua melanggar undang-undang tersebut. Pemahaman tentang undang-undang tersebut harus dilakukan untuk melindungi anak dari perbuatan salah oleh orang dewasa dan orang tua. Sesuai dengan 12 area kritis dari Beijing Platform of Action, tentang perlindungan terhadap anak perempuan.

\section{b Focus Group Discussion (FGD)}

Hasil FGD memperlihatkan berbagai gagasan atau pendapat terkait bahaya penyalahgunaan narkoba bagi siswa. Gagasan atau pendapat yang berkembang dan menjadi fokus perhatian dari kegiatan pengabdian sebagai berikut:

1. Faktor-faktor penyebab terjadinya perkawinan dini di kalangaan remaja.

2. Dampak perkawinan dini di kalangan remaja.

3. pencegahan terjadinya perkawinan dini di kalangan remaja.

Setelah seluruh rangkaian kegiatan penyuluhan di lakukan, diketahui adanya faktor pendorong pendukung dan faktor penghambat. Adapun faktor pendukung dalam kegiatan pengabdian ini, diantaranya:

1. Adanya dukungan dari Kepala SMA Negeri 2 Gerung beserta peran aktif staf pegawai setempat dalam pelaksanaan kegiatan pengabdian mulai dari persiapan pelaksanaan sampai selesainya kegiatan pengabdian.

2. Peran serta Wakil Kepala Sekolah Urusan Kesiswaan menghadirkan para peserta dalam kegiatan pengabdian.

3. Sambutan positif dari Dekan FKIP Universitas Mataram terhadap kegiatan penyuluhan ini.

4. Adanya dukungan dana yang cukup untuk mendukung pelaksanaan kegiatan ini.

5. Materi penyuluhan ini sangat relevan dengan kondisi siswa. 
6. Beberapa pihak terkait turut mendukung pelaksanaan kegiatan sejak perencanaan hingga selesainya laporan ini.

Sedangkan faktor penghambat dalam kegiatan pengabdian ini, diantaranya:

1. Kegiatan pengabdian ini tidak dapat di laksanakan sesuai dengan waktu yang di rencanakan karena warga siswa datang terlambat. Penyuluhan direncanakan di mulai pukul 09.00 namun warga siswa datang jam 09.30 .

2. Tempat pelaksanaan kegiatan ini di aula SMA Negeri 2 Lembar dan sarana yang tersedia juga terbatas, sehingga tim pengabdian Universitas Mataram meminta bantuan kepada bagian perlengkapan FKIP Universitas Mataram untuk dapat meminjam keperluan tersebut. Tim pengabdian Universitas Mataram juga meminta bantuan mahasiswa sebagai operator dalam kegiatan pengabdian ini.

\section{Kesimpulan}

Dari hasil kegiatan penyuluhan dan FGD yang telah dilaksanakan dapat ditarik kesimpulan sebagai berikut:

1. Kegiatan penyuluhan ini terlaksana dengan baik karena di dukung oleh beberapa faktor pendorong, walaupun dalam kenyataannya terdapat faktor penghambat, namun hal itu tidak menjadi penghalang bagi pelaksanaan kegiatan pengabdian ini.

2. Penyampaian materi penyuluhan pengabdian ini dengan menggunakan metode penyuluhan dan FGD. Penyampaian materi dengan menggunakan metode tersebut mendapat respon yang positif dari siswa yang hadir karena materi yang di sampaikan sangat berkaitan dengan dampak perkawinan dini di kalangan remaja di SMA Negeri 2 Gerung Kabupaten Lombok Barat.

3. Berbagai masukan dan idea gagasan dari siswa yang mengikuti penyuluhan dan FGD dijadikan sebagai pertimbangan dalam upaya mencegah terjadinya perkawinan dini di kalangan siswa.

\section{Daftar Pustaka}

Fadlyana, Eddy dan Shinta Larasaty. 2009. "Pernikahan Usia Dini dan Permasalahannya". Sari Pediatri, Vol. 11, No. 2. hlm 136 - 140.

Mubasyaroh. 2016. “Analisis Faktor Penyebab Pernikahan Dini dan Dampaknya bagi Pelakunya". Jurnal Yudisia STAIN Kudus, Vol. 7, No.2, hlm. $285-411$.

Pohan, NH. 2017. "Faktor yang Berhubungan dengan Pernikahan Usia Dini terhadap Remaja Putri". Jurnal Endurance, Vol. 2, No. 3. hlm. 424 - 435. 